\title{
LEXICAL-SEMANTIC SPACE OF THE MODERN GERMAN FAMILY DISCOURSE
}

\section{Osovska I. M.}

\section{INTRODUCTION}

Family communication had been outside the scope of linguistic investigations for a long period of time. In the second half of the XXth century it became more popular, starting from the linguocultural items in the Russian language materials ${ }^{1}$. Some aspects of the family discourse were included in the investigation of the structure and pragmatics of conversational everyday communication $^{2}$, age and gender differentiation of the tactics and strategy configuration $^{3}$. The cognitive-discursive paradigm gives the basis for the definition of family communication as one of the discourse types and the research of its communicative-pragmatic peculiarities in the English speaking society ${ }^{4}$. The aim of the German family discourse study is the determination of the functional-stylistic peculiarities of the family communication ${ }^{5}$, linguopragmatic aspects of everyday communication ${ }^{6}$, linguocultural specificity of the ethical behaviour ${ }^{7}$. At the end of the $20^{\text {th }}$ and the beginning of the $21^{\text {st }}$ century

${ }^{1}$ Байкулова А. Н. Речевое общение в семье: дисс. ... канд. филол. наук: 10.02.01. Саратовский госуниверситет. Саратов, 2006. 290 с. Занадворова А. В. Прозвище и обращение в семейном речевом общении. Русский язык сегодня. М. : Азбуковник, 2001. С. 260-267.

${ }^{2}$ Борисова И. Н. Русский разговорный диалог: структура и динамика. М.: КомКнига, 2005. $320 \mathrm{c}$.

3 Галапчук О.М. Вікова диференціація стратегій і тактик дискурсу в сучасній англійській мові: автореф. дис. ... канд. філол. наук: 10.02.04. Харківський нац. ун-т. Харків, 2000. 18 с.; Піщікова К. В. Стратегії домінування в аргументативному дискурсі: гендерний аналіз (на матеріалі англійської мови): автореф. дис... канд. філол. наук: 10.02.04. Харків, 2003. $23 \mathrm{c}$.

${ }^{4}$ Бігарі А. А. Дискурс сучасної англомовної сім'ї: автореф. дис... канд. філол. наук: 10.02.04. К., 2006. 21 с.; Гридасова О. І. Особливості актуалізації стереотипних ролей в англомовному сімейному конфліктному дискурсі: автореф. дис... канд. філол. наук: 10.02.04. Харків, 2010. 24 с.

5 Смирнова А.Г. Функционально-стилистическое своеобразие семейной речи (на материале немецкого языка): дисс. ... канд. филол. наук: 10.02.04. М., 2008. 178 с.

${ }^{6}$ Mackeldey R. Alltagssprachliche Dialoge: Kommunikative Funktionen und syntaktische Strukturen. Leipzig: Enzyklopädie, 1987. 160 S.; Spiegel C. Streit: eine linguistische Untersuchung verbaler Interaktionen in alltäglichen Zusammenhängen. Tübingen: Narr, 1995. 326 S.

7 Романова Е. В. Этический аспект немецкого обиходного языка: дисс. ... канд. филол. наук: 10.02.04. М.: МГПИИЯ, 2007. 315 с.; Haferland H., Paul I. Eine Theorie der Höflichkeit. Osnabrücker Beiträge zur Sprachtheorie. 1996. 52. S. 7-69. 
the lexical space of a couple ${ }^{8}$ or family ${ }^{9}$ communication also became apparent in the boundless discursive space as on object of continuous topicality, caused by the permanent transformation of a family as a social institution and a small social group.

- Family as one of the environment reference elements, which in the result of a cultural-historic development gained the greatest sense and emotional importance, transformed into one of the symbols of a human consciousness ${ }^{10}$. In this regard, the modern German family discourse becomes an interactive activity of thinking and communicating of the family members as a small group of the German ethnocultural society, which is performed to provide an everyday private individuals' activity through the accomplishment of the practical tasks in the social reproductive process ${ }^{11}$.

The specificity of its verbal realization in the semantic space is based on the dominant items for each family, characterized by certain word-forming and motivational parameters, and form a family vocabulary - familect, known in the modern linguistic literature as 'family language', 'family everyday communication', 'domestic phraseology', 'family dialect', 'family notions', 'family communication', 'family language', 'family lexicon', 'oikolect'12. Familect is a complex of formal and stylistic peculiarities, used within specific family. The core material of the familect is formed of the family vocabulary - modified creation within the lexical fund of the nationwide language, which unites numerous language means, specific for each family. They are used as the basis for the lexical supply of the family discourse - inner family notions, family jargonisms, colloquial language, dialect, sexualisms. The main feature of the familect is a high frequency of those language elements, which emphasize an identity, affiliation of the members to the group - precedential inner family phenomena: nicknames, appelations, denominations, phrases etc.

\footnotetext{
${ }^{8}$ Leisi E. Paar und Sprache. 3. Auflage. Quelle\&Meyer Hedelberg-Wiesbaden, 1990. 167 S.; Loewit K. Die Sprache der Sexualität. Frankfurt am Main, 1992. 240 S.

${ }^{9}$ Нефёдова Л. А. Явление девиации в лексике современного немецкого языка: монография. М.: Прометей, 2002. 260 c.; Fiehler R. Kommunikation zwischen den Generationen: Wunschvorstellung oder Wirklichkeit? L.O.G.O.S. Interdisziplinär. 2007. № 15, 3. S. 200-207.; Kratzmeier H. Du nervst mich, aber ich mag dich: Fragwürdige Sprüche von Eltern und Großeltern. Hildesheim: Bernward, 1988. 88 S.

${ }^{10}$ Osovska I. The analysis of semiotics of the family language as a verbalized area of family discourse. Technology transfer: innovative solutions in Social Sciences and Humanities. Tallinn, 2018. P. 3.

${ }^{11}$ Осовська I.М. Сучасний німецький сімейний дискурс: когнітивно-семантичний і комунікативно-прагматичний виміри: дис.... д-ра філол. наук: 10.02.04. Чернівці, 2014. С. 77.

12 Занадворова А. В. Прозвище и обращение в семейном речевом общении. Русский язык сегодня. М.: Азбуковник, 2001. С. 260-267. Семенюк А. А. Гендерні та вікові особливості кооперативної мовленнєвої поведінки в сімейному дискурсі (на матеріалі сучасної англійської мови): автореф. дис. ... канд. філол. наук: 10.02.04. Донецьк, 2007. 27 с.
} 
The aim of the research consists in the familect specificity description in the modern German family as the lexical-semantic family discourse space.

The research materials include verbal interactions and film scenarios. The method of visual-audio observation with verbal registration of speech facts was used to analyze around 20 hours of spontaneous interactions of three married couples of various age groups H. (25-30 years old, Frankfurt am Main), R. (45-55 years old, Braunschweig) and L. (75-80 years old, Göttingen). The fact that the author of the article was the member of one of the groups, due to long friendly relations, resulted in the maximum natural behaviour of a couple. The great part of the materials includes situations from the modern German literary films and serials of the relevant subject with overall duration of 120 hours.

Taking into consideration an ethic side of the research subject within the selected object, the collection and fixation of the lexical items as the translators of certain intimate aspects common for the family idiolectal discourse was performed as a poll of 100 respondents - direct, as well as through the Internet forums. Regardless of certain imperfection of the method, the results specify the concept of language standards and linguistic conventions in a private sphere of the family space overall and intimate one, in particular.

\section{Methodology}

The research of the familect as a lexical-semantic item of the discourse, which represents emotional-sensual and modal parameters of an individual cognitive space of a person, is based on the lexical-semantic methods accompanied by general scientific ones.

Semiotic analysis ${ }^{13}$ helps to distinguish the core representations of the nominal ideas of the family space in the family discourse - specific nominative acts as the immanent items of different language levels determined by the peculiarities of the referents.

The specificity of the lexical items in the language of a small group consists in the reaction of the language system to the necessity of naming an object or phenomenon, used within its boundaries. A new sign appears as the result of a new meaning formation, becoming a means of particular language tasks fulfillment. They are relevant in a specific discourse and appear as a consequence of an individual search of lexical means for an accomplishment of the communicative task. Accordingly, the structure-semantic and wordformation analyses of the family notions are necessary for the study of communicative processes in a family as a small social group.

13 Лотман Ю. М. Семиосфера. СПб.: Искусство, 2004. 704 с.; Шаумян С. О понятии языкового знака. Язык и культура: факты и ценности: К 70-летию Юрия Сергеевича Степанова: Отв. ред. Е. С. Кубрякова, Т. Е. Янко. М.: Языки славянской культуры, 2001. С. 149-165. 
The study of the core sphere of the family discourse semiotics allows determining and categorizing the items of the family vocabulary. Inner family notions are investigated by the usage of the word formation analysis (the structure research) and motivational analysis (motivational element determination). The peculiarities of the lexical-semantic space of the German family discourse, discovered by the method of linguistic observation, are classified and interpreted on the basis of a contextual analysis. The great role in a range of the relevant methods of the family discourse lexical level research plays the descriptive method with such main constituents as observation, generalization, interpretation and classification ${ }^{14}$.

\section{Family language semiotics}

The former investigations state that the specificity of the family language, first of all, makes possible the symbolism of the language system elements $^{15}$, while the main representation of symbolic notions of the family space is a range of specific denominations ${ }^{16}$.

Taking into consideration the main types and features of the signs, according to Ch. Peirce, - sign as it is, its meaning and syntagmatic functioning in an interaction with others ${ }^{17}$, we can note the whole range of features of semiotic essentials ${ }^{18}$ in the inner family notions. However, the core sense of 'sign' in the family discourse lies within a division of signs to icons (similarity with a thing), indexes (transformed similarity with a thing) and symbols (dissimilitude with a thing, thus with an interpretation based on a precedent). In particular, in the context of the family discourse iconic inner family notions are fixed. Their inner form includes description (for example, height or age das kleine Paulche), hypothetic future (successful career of a model - unser Star-Modell or musician - Mozart aus Usedom), fact from the past (for example, the former profession - Gas-Klaus), denotata, as a separate element of a scenario (may raise the voice - die Schrei-Mädi) etc. Signs-indexes, which are related to denotat, may be considered as various types of speakers'

${ }^{14}$ Комарова 3. И. Методология, метод, методика и технология научных иследований в лингвистике. 2-е изд., испр. и доп. М.: Флинта: Наука, 2013.820 с.

${ }^{15}$ Osovska I. The analysis of semiotics of the family language as a verbalized area of family discourse. Technology transfer: innovative solutions in Social Sciences and Humanities. Tallinn, 2018. P. 4.

${ }^{16}$ Осовська I.M. Сучасний німецький сімейний дискурс: когнітивно-семантичний i комунікативно-прагматичний виміри: дис.... д-ра філол. наук: 10.02.04. Чернівці, 2014. C. 240-264.

${ }^{17}$ Пирс Ч. С. Избранные философские произведения. М.: Логос, 2000. С. 53.

${ }^{18}$ Osovska I. The analysis of semiotics of the family language as a verbalized area of family discourse. Technology transfer: innovative solutions in Social Sciences and Humanities. Tallinn, 2018. P. 5. 
cooperation within the family discourse, which provides the referential relations. As a consequence, an individual-interpreter attains the orientation points, which help to reveal the meaning of scenarios, in which he or she participates and gets an ability of a successful orientation in a family space. The majority of signs in the family discourse are the symbols, so far as they give a reference to a family space associatively, including an index or other indirect way, for instance, the usage of love poems, where the elements of a complex sign may be characterized as iconic - private notions common for denotat. The collection of sign elements makes it possible to juxtapose the denotat with an informational structure through indexation, which in certain situational family context is used as a symbol - 'switch on', that proves an 'adequacy' of information and allowance for the development of one of a family communication scenarios ${ }^{19}$.

Consequently, the presence of a strong estimation and value components in the family discourse structure gives the ground to claim about the global symbolism of the items, which denote them, in the language of modern German family. This symbolism is peculiar only to the most significant, for an individual, cultural facts related to the values ${ }^{20}$.

The symbolism of a 'family' sign, stipulated by the precedent-based interpretation, allows us to confirm the common apperception basis and precedent-setting features of the family discourse on the lexical level. The foundation of the 'family precedence' is an experience within the boundaries of the collective cognitive space - common (recognizable, usable and cited by other members of a family group) memories, which determine a selfidentification of a person as a family representative, who accept its values, norms, ideas, priorities, tastes and traditions. It gives a representative an ability of orientation in the present socio-cultural environment, arranges a vital activity, anticipates its consequences, and allows certain type, manner and form of communication. Symbolic family precedent items are also represented by other complex signs. Among them are jokes, situations, stories, which happened during some important family events like weddings, christenings, vacations, birthday parties and holy days, as well as such significant family events as repair, removal etc. Family precedent can be considered as a family (verbalized or non-verbal) stereotype, unknown or little-known outside its boundaries.

The lexical level of the familect is represented by names and nicknames, which guide to an inter-subjective group space and put a speaker in a certain

${ }^{19}$ Osovska I. The analysis of semiotics of the family language as a verbalized area of family discourse. Technology transfer: innovative solutions in Social Sciences and Humanities. Tallinn, 2018. P. 5.

${ }^{20}$ Красавский Н. А. Эмоциональные концепты в немецкой и русской лингвокультурах: монография. М.: Гнозис, 2008. С. 21. 
position within discursive structure, catalyzing the discourse type from the side of a speaker-initiator and transforming it into a special 'navigator' for a speaker-recipient.

Traditional status and role nicknames and their derivatives in the German family have a range of modifications: shortened denominations (Mutti, Mom, Mama, Mami, Mudda, Vatti, Vadda, Papa, Dada, some clearly express an influence of Americanisms), pronoun of address du (Du, Mama, gib mir was zum Schreiben!), address to parents by names (Gabi, gib mir ein Buch bitte). Symbolic components of the family discourse are also expressed by typical pet names (feel-onyms) (Schatz, Engel, Liebling, Puppe) and zoonym pet names (Bär, Maus, Hase, Biene, Frosch, Schmetterling, Maikäfer, Spatz, Tunfisch, Tiger, Büffel) with numerous derivatives (Engelchen, Schätzchen, Püppchen, Schatzi, Stupsi, Herzlilein, Schlaue (s/r), Süße (s/r), Kleine (s/r), Schöne (s/r), Bärchen, Mäuschen, Mausi, Mausilein, Mäuselchen, Hasi, Brummbär, Goldbärchen, Mausbär and others).

The main discursive symbolism of a sign demonstrate proper names as symbols, which undergo an indexation through modification mechanisms, despite an appealing designation, situationally get positive and negative connotative shades, symbolizing a type of the family discourse - cooperative, where a positive evaluation is marked, for example, on the phonetic level (Gabi, Lisi, Hanse, Ronaldo, Peterli, Roserl, Lising, Antje, Klausilein) or by the widen metric name (Sandmännchen (Sandmann)), or confrontational, activated by certain substitutional mechanisms (Radeklepner (Rademacher), Scheißhenne (Mayer-Henne). As a rule, family language includes strategically adequate double names of one and the same person, created by various phonetic and lexical means (Hoa, Colli / Fanta, Dala in cooperative, Horst, Nicole, Daniella in confrontational communication).

Emotionally-valued meanings may be marked by certain phonetic means, substitutionally, by the shortening or widening of a metric name. Lexemic modifications of a surname as a derivative basis are created by synonymic or antonymic forms. Individual denominations are also popular ${ }^{21}$.

The inner family nicknames in the family discourse have a status of descriptive signs, stipulated by a polyfunctionality, expressed by onomastic and communicative-pragmatic functions. They can describe an appearance (Hexchen - tousled hair, Spargel - height, Tonne / Dicki / Birne - obesity, Bart - presence of a beard, Schädel - bald spot, Mozart - curly hair), temper (Knoten - stubbornness, Paprika - temperament, Seele - soulfulness, Zwerg greed), behaviour (Stopfer - glutton, Pieps die Maus - low voice, Mimose -

${ }^{21}$ Osovska I. The analysis of semiotics of the family language as a verbalized area of family discourse. Technology transfer: innovative solutions in Social Sciences and Humanities. Tallinn, 2018. P. 4. 
delicacy, Party-Huhn, Lisi V.I.P. - party lover), residence (Zwettler Oma, Wolfenbuttels Cheriff), documental events (Gretchen - participation in a school play 'Faust' by J. W. von Goethe), being unknown to a person (Spitznäschen younger daughter, who hates her appearance because of a snub nose; Zugvogel - son, who often changes his work place), functioning in a small family circle (Fee und Prinz) or being popular among a wide circle of relatives.

The inner family denominations have fixed rational and mythological (Edembewohnerin, Brunhilda, Kronjuwelle, Satansbruder, Nebelkrähe, Megäre, Gewitterhexe) motivation. Non-obvious motivation characterizes the denominations in the meaning structure of which the univerbation of syntactic totality is shown implicitly. Semantic community of transpositions is based more on individual associative features, than on common semes - for example, Investor - father as a person, who invests in financial future of his children; Solist - lone person, who plays the first and only fiddle in his life.

On the basis of the apprehension of a systematic word-forming model shown in permanent relations, during the process of inner family nicknames creation, some classic word-forming samples are noted: suffixal, prefixal, prefixal-suffixal, composite, root words, non-affixal ${ }^{22}$.

The majority of composite words with anthroponymic components (Schnitt-Kai, Zug-Sebi), binding (Ökoutchen, Küchenkati, Meckerrony, Frierkatja, Quatschliese, Lachmaja) and analogical formation (MöchtegernKlaus, Gerneklug-Hardo) are characterized by intercomponental implicity.

The German family discourse is often denoted by constructions, formed in accordance with a sample 'motivator' + (modified) proper name/surname (supportive component)', which unite an attribute and anthroponym (der junge Rademacher), appeal and anthroponym (Ach-Marta), several anthroponyms (Zopf-Kristian, Pinsel-Hardo, Brillen-Klaus), toponym and anthroponym (McDonalds-Mia).

Suffixation of a lexeme is aimed at personification (Schmarrer, Krämer, Bluffer), or qualitative subjective estimation (Nervi, Provo, Schizo). Semantic nature of a few prefixation cases consists in the explication of a nominative case (Antipapa).

The most effective method of the family nicknames creation is a usage of other names, objects denominations, images by virtue of associative dependency, which through the prism of semasiology is a process of a specific discursive sign symbolization, when the weakening of a referential juxtaposition is compensated in an inner form by the strengthening of descriptive semes (Einstein, Don Juan, Napoleon, Lorelei, Woody, Micki und

${ }^{22}$ Осовська I.М. Сучасний німецький сімейний дискурс: когнітивно-семантичний і комунікативно-прагматичний виміри: дис. ... д-ра філол. наук: 10.02.04. Чернівці, 2014. C. 250-253. 
Mausi). Moreover, an associative field of each word is formed on grounds of an individual meaning features and psychological peculiarities of a speaker, which are not always obvious.

In addition, great attention is paid to the names of household items and tools, which implicitly illustrate certain quality, comprehended in some other way and directed to a person (Tanker becomes a denomination of a big and persistent family member, Emmentaler - a lover of the same named cheese).

The specificity of the family discourse creates peculiar abilities for the nominative process, where they globally transform its mechanism into semantically implicit. An occasional nature is fixed not only within special methods of standard samples relevance (das Elter (die Eltern), Bete (Beate), but also in the usage of not typical, out of norm formats (die Daniella (Daniel), Herzmatikus (Rheumatikus) or entire models.

The nicknames created syntactically or by word-forming are simultaneously signs and deictic markers, which include a reference to the informational structure 'behind the scenes' of a lexeme. Thus, the denomination Micki und Mausi refers to the scenario of a cooperative parental interaction, where the concept KINDER implicates such features as klein and befreundet. A complex sign Mädi V.I.P. not only names a person, but also indexly emphasizes on the denotata characteristics, categorizing it as Frau aus den hohen Kreisen / Powerfrau / wichtige Person.

As a conclusion, the German inner family nicknames appear as signsnames with certain implicit meaning in an inner form, which indexly correlates denomination with the sphere of origin: appearance, features, and habits. In the communicative-pragmatic point of view, an absence of nicknames affirms a worsening of relations, general conflict atmosphere of the family discourse or complication by permanent or occasional conflict situations.

\section{Peculiarities of the family lexicon}

The sphere of family denominations demonstrates the level of a speaker's creativity within the limits of self-realization and various levels of 'presence' of a speaker in the discourse - neutrality and activity, observed during both, the creation of family nicknames and nomination of things, objects and events. Active 'presence' of a speaker widens the family lexicon through an inner family new creations, which appear as a result of: a) innovation in speech, that keeps a semantic word structure (for example, Doofino denoted as silly, senseless action); b) formation of new meaning as a consequence of permanent word usage (personalization of, for example, Blech, Gretchen, Elefant - cars, die Macht - remote controller , Volltreffer - good mark, Regenbogen - mother, who rarely appears at home because of business trips, Schlenderei - corridor). 
It might be assumed, that the formation of the family denominations not only structurally, but also semantically, allows the deviation of references and techniques, that provides positive refocusing of negatively connotative (Rübe, Fratz, Ziege, Kröte, Hexe, Wurmi) and even pejorative items (Miststück, Mausespeck, Pappnase, Scheißerchen, mein Stinker, kleine dicke Hummel).

Affiliation to small groups inside a family (matrimonial and parental; gender and age) is also objectively present in the meaning structure of family denominations and influences the selection of lexical-grammatical means by the speakers. Thus, for instance, from an ethical standpoint, indecent jokes are conditionally 'permited' only in the same age category, while conversations on topic of physiological peculiarities of an organism - only in the same gender group. Generally, the family discourse demonstrates moderate gender (more frequently - anti-feminine) asymmetry (Klatschweib, Giftspritze, Schlange, Dreckliese, Dorfquatsche, Kratzbürste).

Precedential nature of the given items provides their status of 'access codes' to the conceptual discursive family system as an informational domain. While choosing an adequate language item, a speaker subconsciously and associatively juxtaposes them with both, a range of verbalizers of a discourse forming concepts and main cognitive discursive scenarios of family communication.

Discursive precedence (repentance and family usage) underlying in a secondary denomination reveals not only the names of people, objects nominations, but also situations, texts or expressions. Thus, the fixed examples of the German language family verbalized and non-verbal symbols include a necessary kiss when people meet each other, raise of hand in a crowd when searching for somebody or showing a desire to express oneself, whistle to message about a set table or „M\&M’stest” (guessing a partner's mood according to the eaten chocolate candy colour), standardization of onomatopoeia of the nature, cars, drums, clock ticking. Familect may be special in the usage of precedential expressions of the literary origin: 'Alle spielen hier Theater' (W. Shakespeare), 'Ich weiß nicht, was soll es bedeuten... (G. Heine).

Family communication may be characterized by a significant tendency called intervention of the elements of other style or out of genre, especially in specific spheres of the family discourse, in particular, intimate one (Geschrieben ist, am Anfang war das Wort; Es sei darauf hingewiesen, dass du nicht recht gehabt hast).

Some precedential cliché expressions (for example, So hat immer Oma gesagt; Das sind Mama's Worte; Ich kenne nicht den Grund, aber sie hat immer das wiederholt) belong to the category of individual senses as emotionally marked and available for the comprehension of other family members without getting the code before its decoding. Family discourse is also composed 
of certain precedential situations, like the ones saved in the memory and due to the presence of iconic element become symbolic in the family discourse: Aber bitte nich wie gestern, gegangen und alles vergessen (to wife, who forgot to throw out the trash); Haben wir schon mal was verloren (a story about a bag left in the shop, known to family members); Jemand war schon mal am Meer ... (reminder of a situation, when father had almost drowned in the see). Every day family sources enrich the familect in the process of daily life, children language, based on expressively marked events, slip of the tongue or slip of the pen of family members.

Semantics of the family lexicon proves that its items stand for signs of a peculiar nature with word-forming and semantic non-typical features, motivation and sometimes unpredictable meanings, as well as expressiveness. They are modified symbols, supportive elements, invariable core that unites the world view of the family members.

Substandard phenomena are also an important component of the German family discourse lexical basis. They consist of slang as both, sociolect as the most dynamic part of the lexical-semantic system of the German language, and dialect as its socio-functional type, which mark a group identity strategy as a systemically inherent that makes the boundaries between standard and substandard blur.

Family discourse as a space of the family society produces a conglomeration of sociolects - child one as an aspiration for imitation, teenage as a desire of 'alienation' from an 'adult society', youth with a 'special signal function and playing manner of the language usage, ${ }^{23}$, creating an exclusive familect. An obvious presence of slang in all types of the family discourse is expressed by language playing features for the variety of socially equal participants (matrimonial), while for the family communication of different social level (parental) - cryptolalic that gives the meaning of a secret language of a group.

Family slang is opposite to the literary language. As an informal, stylistically lowered, functionally limited phenomenon, family jargon has the functions of expressiveness and valuation.

The analysis of the given family discourse component makes it possible to note jargonisms of: big and friendly family (Aus-ein-und-demselben-GlasTrinker, Clique, Schnullerfamilie); marriage / divorce, betrayal (Zweipersonenmodus, aufs Ehepferd steigen, die Kuh kaufen, ein junges Talent verpflichten, legalisieren, Ringe werfen, Sich-ver-heiraten, friendgehen); wife / partner (Alte, Atta-Girl, Beschärmede, bessere Hälfte, Bettgenossin, Bodeningenieuse, Ehehälfte, Ehefotze, Ehenutte, Ehekrüppel, Fußbodenkosmetikerin, Gemahlin, Gespielin,

${ }^{23}$ Heinemann M. Kleines Wörterbuch der Jugendsprache. Leipzig: Bibliographisches Institut, 1989. $122 \mathrm{~S}$. 
Herzdame, Nebengeräusch); husband / partner (Alter, Altarhäschen, Beteiligter, Beischläfer, Bubba, Co., Compagnon, Dude, Feigendepp, Fotzenknecht, Hauptrechner, Unter dem Pantoffel); child (Balg, Bankert, Bauchbewohner, Blagen, Drecksmade, Fickfehler, Flurscheisser, Fruchtzwerg, Gör, Haiei, katholisches Kaninchen); father (der Alte, Familienoberhaupt, Familientorpedo, Familienschreck); mother (die Alte, Familienmanagerin, Gebärmaschine, Raumpflegerin); parents, the older generation (Komposti, Grufti, Friedhofsgemüse, UHU (unter Hundertjährige), Kohlenbeschaffer, haben Mumienausweis/Runzelpas, Noch-Berufstätige, Experte, Exzentriker, Clown); the uppbringing (Erzug).

According to the informants, the family discourse uses highly effective slang words-nominators of the main life processes and subjective groups, for example: food and the process of consumption (Brikett, Fraß, Fressen, Haveritis; hinter die Binde hauen, beißen, dinieren); drinks and the process of drinking (Gsiff, Schaumtüte, Schlurre, Schwemme, Schwenze, gießen, piperln, püttkern, rotzen); alcohol intoxication (angeblasen, angedonnert, angeflaschelt, angesäuselt, angestochen, ausgeflippt, beduselt, Fetze, Glut); smoking (Karlschachter, Lungenbrötchen, Lungentorpedo, Nikotinnudel, Stummel, eine Abgerissene heizen, nebeln, paffen, puffen, schmökern); clothes (Brocken, Brustgeschirr, Decke, Fassade, Fetzen, Hülse, Hupferspreizn, Janker, Kittel, Kluft, Kotze, Maskerade, Panier); financial transactions (Blüten, Fetzen, Flak, Ischlinge, Knöpf, Plärrer; ausbluten, blechen, gestapft sein, schaufeln, löhnen); professions, work / idleness (Kähle (Arzt), Putzer (Frisör); bremsen, buckeln, hakeln, knausern); means of transport (Affenschaukel, Asphaltblase, Düsi, Flitzer, Flieger, Furzerl, Glühi, Karren, Kraxn, Kübel, Leibschüssel); body parts (Bollen (Oberschenkel), Brotladen (Mund), vier Buchstaben, Dääz (Kopf), Döppen (Augen), Flossen, Fotz, Fresse, Globus, Gnack, Hespen (Beine)); physiological processes (AA machen, brechen, Dünnpfiff, Dünnschiß, entleeren, gacken, ludeln, pforzen); state, mood and processes (angerührt, angespeist, angefressen, anzipfen, arg, geht mir auf die Eier, ikeabel (reife und stabile Beziehung, die sogar einen IKEA-Besuch übersteht), mir geht das Hammerl (wütend sein), Hammer, high sein (richtig gut sein), mir fallen die Keks obi, kein Leiberl haben, öd, einen Pecker haben, bei dir piepts wohl (keine Geduld haben), hochunbegabt (in bestimmten Bereichen ohne jede Begabung), hell auf der Platte sein, ihm geht der Reis, mir geht das Sieberl, ätzend (unmöglich), booor ej (widerlich)); names and descriptions of people (Tussi, Schnalle (Mädchen oder (junge) Frau), Zombie / Gruftie / Kompostie / Oldie (alter Mensch), Kretin (Dummkopf, Idiot), Busselkatte (unruhiger Mensch), Fruiseküttel (Mensch, der schnell friert), Heudommes (nutzloser Mensch)); names of objects (Äslämmeken (Klinke in der Hose), Glotze (Fernseher), Gedöns (unordentliche Ansammlung von Gegenständen), Hasenbutter (ein Butterbrot, meist „Zugeklapptes”); processes 
and actions (eine Show abziehen, anmachen, baseln (sich ungeschickt und hektisch/laut bewegen), betuppen (mogeln, bescheißen), blinstern (blinzeln / versuchen, genau hinzusehen), blirken, blierken (mit heller schriller Stimme sprechen), busseln, burseln (wühlen)); description of people, phenomena, processes and objects (belämmert (dumm), blösig (windig), dörroin (verwirrt), druihörig (stur), etterig (streitsüchtig), ferme (heftig), harre (laut), hibbelig (nervös, zappelig), kruselig (kraus, unordentlich liegend)).

In general terms, family slang demonstrates both, deviation from the rules and implementation of creativity for the formation of a new language item. Practically, they are innovative in the sphere of meaning and expression and cover the morphological (hypermäßig, Spasti, realo) and lexical-semantic (rotieren (zu viel zu tun haben und den Überblick verlieren), tanken (trinken), nicht richtig ticken (verrückt sein)) levels.

The dominance of jargonisms in one of the partners' language (for example, frustriert, motiviert, sensibilisiert, paranoid, schizophren, orale Gelüste for a professional psychologist) may lead to the communicative deviations in matrimonial discourse.

Another significant peculiarity of the German family language is the usage of dialect as the most archaic language level, medium of family communication and identification. This is confirmed by the poll of respondents, who claim of dialect predominance in $62 \%$ of the modern German family communities.

Stereotypic conception about the fact that 'in the majority of German territory, dialect corresponds with a cognitive deficit, low social status and culture $^{24}$, correlates with a statement that the German community representatives of different social positions not only have a favorable attitude to their native dialect, but also know several other dialects, can add certain dialect expression to the literary speech, communicate using colloquial language, which is close to dialect ${ }^{25}$.

Taking to consideration a choice of the researchers of colloquial dialect forms, for the analysis we select literary adapted (artificial) dialect that contains special features of dialect and is available to the reader. We determine the dialectal peculiarities of the German family discourse supplementing it with the samples from the works of linguist-variantologist W. Näser ${ }^{26}$.

Due to the informants, generally, the genre of family communication stipulates a switch to dialect. The usage of the literary language by a dialect native speaker in certain intimate situations is usually inappropriate.

${ }^{24}$ Löffler H. Germanistische Soziolinguistik. Berlin: Erich Schmidt Verlag, 1994. S. 161.

${ }^{25}$ Меркурьева В. Б. Литературный язык и диалект в естественной и художественной коммуникации. Теория и история германских и романских языков в современной высшей школе России. Калуга : Изд-во Калужского госпедуниверситета, 2002. С. 6.

${ }^{26}$ URL: http://staff-www.uni-marburg.de/ naeser/dial-bsp.htm. 
The functioning of dialect in the family discourse is revealed, first and foremost, in the usage of address forms of a dialectal nature. Suffixes -i, -lein, ili modusly mark the expressions (here and further the form of records from the sources is maintained): - Chum jetz, Hansli, chum, was, jo das hemmer s'letscht Mol scho agluegt, chum jetzt, he jo, mier gönd wieder einisch is Verchehrshus, natürlich, chum jetzt, chum. Was? Was das isch? Das wirsch wohl wösse, eh jo, 's isch jo no agschribe, eh jo, Swissär schtoht jo droffe. - Nur no ei Bussi, bitte!

Through an indexation of intimacy and familiarity, the diminutives provide a scenario of a cooperative family interaction: - Hallöchen, Gabirle! Bring mir doch so ein Kofferle mit seinen Klamotten. Schau, wie ich des gmacht hab, vielleicht kriegst dus raus, wenn de dir mal sowas ankuckst.

Dialectal suffixes -li and -la may index insincere, contemptuous attitude to a partner: - Lass mich doch in Ruh, Pauli, altes Scheißbubi! - Morräing Schatzla, kann ikk fütt di jätz, jätz morl ... 'n Schdück Porräing kriegn?

Spontaneous switch to a dialect in any of a speaker's phases (even in conditions of general acceptability of the literary language usage) is expression of symbolism of a sign in the family discourse, which is performed with an aim to paraphrase, reform (Das ist gar nicht wahr. Des is net wohr), mark the beginning or end of thematic unity (Also, Schluß mit der Vorstellung. Setzts aich niede...), change the mode of conversation, turn to other scenario.

\section{Family discourse global strategy marking}

The basis for verbalization of the global (cooperative / confrontational) strategy in the family discourse is language subsystems, the items of which 'switch on' the relevant meanings in speakers' consciousness. Among such subsystems are intimate vocabulary and language play (for cooperative family discourse), invectives (for confrontational family discourse)

Among principle features of the matrimonial discourse are emotionality, rituality, symbolism, frankness, culturally determined non-verbal code. Respectively, the fundamental functional subsystems of an idiolect of a couple are love, sex and play, which on the lexical level are expressed through a private code. By encoding an intimate individual sense using maximum individualized denominations, the participants of the matrimonial discourse identify relationship as 'exclusive', and themselves as the members of a 'minigroup'. An intimate sphere of the matrimonial discourse is maximally individualized, 'cryptonimicly esoteric' ${ }^{\text {, }}$.

Private code is expressed by numerous denominations-feel-onyms exchanged between communicants: Ampel, Bobole, Butz, Büsi, Chatz, Chatzli,

${ }^{27}$ Ренц Т. Г. Романтическое общение в коммуникативно-семиотическом аспекте: автореф. дисс. ... д-ра филол. наук: 10.02.19. Волгоград, 2011. 42 с. 
Cremeschnittli, Siebenschön; Aasgeier, Biestli, Böckli, Bubi, Cheri, Frosch, Fui, Häsi, Hedgehogli, Igelchen, Kobold, Leu, Löffeli, Lümpli, Manunggel, Munggel, Mutzer, Mutzli, Pigel Piglet, Pip; Chäfer, Darling, Dummerli, Herzblatt, Holde ( $r$ ), Honey.

Diminutives play an essential role in the matrimonial discourse. Their predominance is explained rather by the desire to use a diminutive denotation than by an affective condition of a speaker. Level of its creativity is also variable: the majority of denominations is traditional (Mausi, Käfer, Häschen, Schnucki), transformed (Schnuckiputz $\rightarrow$ Schnugi / Schnügel / Butz) or semantically metaphorized. New creations are noted (Schabidu, Schmüderli, Fui, Pip, Nanu, Ladli, Hagara, Schä), the etymology of which is obscure. Creation of new words and new design of existing forms may be considered as an indication of private language as a specific group variant. Some couples limit it to several phrases, while others develop it to the status of the original language of a couple (for instance, 'Nuh deh alleliebsse Pumbusch es bikenke, weil sölm bifundsteint!' ${ }^{28}$ ).

For a long period of time, intimate denominations had been a prerogative of 'man' vocabulary. This situation has changed only with a change of social grounds. The poll confirms that in conditions of maximum disposition to the literary language (79\% of respondents), German people use sexual literary denominations in the matrimonial discourse in quite reserved manner (28\%). However, sexual denominations of vulgar language - 'style that is regarded as rough and lowered, contains taboo notions and formulations, which in this social space concern to the spheres related to shame and disgust ${ }^{29}$, despite its general unpopularity (15\% of respondents), almost preferentially are used in an intimate sphere of the German matrimonial discourse (86\% of cases).

Respondents distinguish the principle intimate denominations and metaphors of sexual sphere of a couple, the most frequent of which are denominations of intimate zones: Amors Pfeil, Asylbewerber, Banane, Barometer, Blasrohr, Dauerbrenner, glatzeter Knabe; Balkon, Birnen, Milchfabrik; Batterie, Fotze, Motorraum, Muschi, Pelz, Steckdose. Categorization of data obtained from respondents gave an ability to generalize the categories of 'sexual' metaphors: movements and actions (ausklopfen, in die Büchse rühren, bügeln, bürsten, polieren); permeation, filling (bohren, in die Büchse rühren, eintunneln); beating (ausklopfen, puffen, stempeln); sports activities (kegeln, ringen, rumturnen); struggle, aggression, destruction (anschießen, ausbomben, clinchen, umhauen); denominations of body, sounds, animal actions.

\footnotetext{
${ }^{28}$ Poth C. Taktik des Ehekrieges. Fischer Taschenbuch Verlag, 1996. Bd. 2484.

29 Leisi E. Paar und Sprache. 3. Auflage. Quelle\&Meyer Hedelberg-Wiesbaden,
} 1990. S. 148. 
Obviously, the literary language that provides only 39 denominations within the notion of 'sexual contact' metaphorizes 'material' aspects of actions without implementation of volitive aspects. Explicity of vulgar language in denomination of certain aspects of sexual activity contributes to vivacity and demonstration, which speakers bear in mind claiming that it 'transports desire and attraction ${ }^{30}$. Aggressiveness of vulgar language causes its legalization only through allowing mechanisms, implicated in a private code.

Situational characteristic of the German family discourse often consists in speaker's positively directed psychological instruction with the elements of language play, which is practically a range of metasemiotic methods, 'based on knowledge of language items system, norms of their usage and ways of their creative interpretation, ${ }^{31}$.

Specific language code that is formed in relationships and then transformed into communication with descendants, distinguished by the growing need in spontaneous communication, creates the frames for a play experiments. Demonstration of language play may be viewed as morphological variants, syntactic or syntactic-semantic deviations, inobservance of semantic congruency - rules for the logical structure of words combination, usage of modified foreign words and expressions, stylistic shifts ${ }^{32}$. In general, the frequency of language play usage can be testified as healthy micro-climate of the family.

Expression of negative emotions is characterized by a higher level of creativity and demonstration than positive ones, as soon as 'person becomes sincerely natural and clear only while quarreling'. 'Blessing has always been the same, - and conversely, curse has always been diverse' ${ }^{33}$.

Aggressiveness of confrontational communicative mode is, first of all, implemented in an invective colloquial vocabulary as system of signs, which 'catalyze' an inclusion of a confrontational family discourse to the scenario. Regardless of the fact, that the invectives are stylistically marked as rough and vulgar, appears an idea of their justification due to certain life conditions as a password, means of contact establishment, self-presentation as a person free

${ }^{30}$ Deppert A. Die Metapher als semantisches Wortbildungsmuster bei englischen und deutschen Bezeichnungen für Geschlechtsverkehr. Sprache - Erotik - Sexualität. Hobert R. (Hrsg). Berlin: Erich Schmidt Verlag, 2001. S. 148.

${ }^{31}$ Санников В. 3. Русский язык в зеркале языковой игры. М.: Языки русской культуры, 1999. С. 13.

32 Осовська I.M. Сучасний німецький сімейний дискурс: когнітивно-семантичний і комунікативно-прагматичний виміри: дис.. д-ра філол. наук: 10.02.04. Чернівці, 2014. C. 291-295.

${ }^{33}$ Müller H. Heute wär ich mir lieber nicht begegnet. Frankfurt am Main: Fischer Taschenbuch Verlag, 2010. S. 225. 
from superstitions, the process of taking attention, an expression of trust, shortening of interpersonal distance, rebellion etc ${ }^{34}$.

Investigation of the verbal component of the German family discourse, socially relevant basis of which is the widening of boundaries of what is acceptable in practice of the daily-life language, make it possible to confirm a bigger role of bad language under the circumstances of transformation of moral norms and family principles towards a disappearance of authoritarianism and higher level of tolerance. It seems that Germany as the lawful government with strict monitoring mechanisms managed to form a social system not only of legislative, but also moral, subconsciously controlled, objectively effective means of deprecation, implemented through the laws and orders, as well as developed and fixed in several generations moral and legal society efforts. This condition explains an exceptional permission of the functioning sphere of the invectives or limits of a core zone of discursive environment, or its conditionality of a high emotional expressiveness.

The fundamental point of invective vocabulary in the German language consists of a few generally known origins. The periphery is inaccurate, and its limits are conditional and set by social conventions. This layer of abusive pejorative vocabulary, which expresses negative attitude of a speaker towards an addressee, state of affairs or situations, is a main body of an invective field, activated in confrontational type of the matrimonial discourse.

Among the fixed semantic groups of pejoratives are those which denominate: negative features (of a wife: Dreckstück, Fotze, Fut, Kuh, Sauweib, Schlampe, Socke, Zicke; of a husband: Arschloch, Bengel, Depp, Drecksack, Hundesohn, Schuft, Schweinehund, Trottel); appearance (of a wife: Birne, Biest, Brett, Bohnenstange, Bügelbrett, Männerschreck, Sauluder, Schachtel; of a husband: Frauenschreck, Krauterer, Sack, Zottelbock) and partner's age (old age (for a woman: Schachtel, Schaluppn, Scheune, Spinatwachtel; for a man: alter Bock, Knacker, Krauterer); youth (for a woman: Gemüse, junges Ding, junges Stück; for a man: Grünschnabel, Hosenscheißer, Lauser); personality traits (of a woman: foolishness (Dummkopf, Gans, Hendl, Kuh, Trottel), anger, quarrelsomeness (Beißzange, Drache, Furie, Giftspitze, Hausdrache, Zange), talkativeness (Dorfklatsche, Klapperschlange, Klatschweib, Maulheldin, Schnattergans, Schwätzerin, Schlabberschnute), alcohol addiction (Schnapsdrossel, Säuferin, Schnapsschwester); of a man: foolishness (Blödmann, Depp, Dummerjan, Dummkopf, Kaffer, Lotter, Narr, Sachafskopf, Sepp, Trottel, Schleicher), rudeness, clumsiness (Bauer, Bauernflegel, Flegel, Grobian, Lackel, Lümmel, Rüppel, Rustikus, Runks), egoism, arrogance, bluster (Bramarbas, Geck,

34 Жельвис В. И. Поле брани. Сквернословие как социальная проблема в языках и культурах мира. М.: Ладомир, 1997. 230 с.; Форманова С. В. Інвективи в українській мові: автореф. дис. ... д-ра філол. наук: 10.02.01. Одеса: ОНУ імені І. І. Мечникова, 2013. 39 с. 
Gockel, Pfau, Prahlhans, Protz, Schniegel, Schnösel), weakness of will, spinelessness (Pantoffelheld, Pisser, Schlappschwanz, Waschlappen, Weib, Wicht), alcohol addiction (Alki, Branntweiner, Saufer, Schnapsbruder, Trunkenbolt), adulation (Arschlecker, Arschkriecher, Arschkratzer, Buckelmacher, Speichellecker), cowardice (Angsthase, Bettscheißer, Hasenfuß, Hosenscheißer, Hosenbrunzler, Pisser); sexual behavior (men unscrupulousness: Casanova, Gockel, Hurentreiber, Hurenbeutel, Hurenbock, Schürzenjäger, Weibernarr; women accessibility: Betthäschen, Dirne, Fickfrosch, Flittchen, Hure, Horizontale, Matratze, Nutte, Pritsche, Schlampe, Schlitten, Strichmädchen); profession (of a man: Aktenhengst, Bürohengst, Bürohans, Bürofritz, Federfuchsler, Paragraphenhengst, Sesselfurzer, Schreiberknecht, Tintenpisser; of a woman: Bürolampe, Büroschickse, Büroklammer, Bürowanze).

Metaphorical pejorative expressions, fixed in the matrimonial discourse, designate: domestic animals (Esel, Ferkel, Hammel, Kaninchen, Kuh, Pferd, Schaf, Schwein, Ziege and hyperonyms Tier, Herdentier, Vieh, Wildling, Bestie); birds (Gans, Hendl, Huhn, Pute); reptiles (Natter, Kobra, Schlange, Wurm); insects (Floh, Laus, Käfer, Schabe, Wanze and hyperonyms Insekten, Parasiten, Schädlinge); exotic animals (Affe, Hyäne, Kamel, Pfau, Ratte): Kannst du dich nicht schneller bewegen, du Kamel. - Lassen wir das. - Gar nichts lassen wir, du dumme Ziege!); plants (Birne, Gurke, Pflaume, Tomate, Unkraut); objects (Fettsack, Mehlsack, Puppe, Schachtel, Schraube, Stehaufmandel, Waschbrett, Waschlappen); organic waste (Dreck, Mist, Rotz, Scheiße); historical and mythological characters (Biest, Casanova, Drache, Hexe, Judas, Monster, Neandertaler, Satan, Teufel, Xantippe, Zwerg); body and spirit defects (Debile, Geisteskranke, Idiot, Krüppel, Siech, Wahnsinniger).

Metonymic pejoratives are also frequently used (Arsch, Arschloch, Fotze, Schwachkopf, Geizhals, Großmaul, Ohrfeigengesichter, Menschenschwanz, Miss Silikontitten, Scheißkopf) or those with metaphorical transformation (Schweinesack, Hundsfotze, Stiernacken, Fratze, Affenarsch, Affenschädel, Schafskopf): - Halt's Maul! - Sperr den Schnabel auf! Pfoten weg! („Kokowääh”).

Pejoratives are commonly deemed as the markers of a confrontational family discourse. However, they may be noted in other types of the family discourse as word-forming elements for a translation of a speaker's state through his/her negative attitude to an object or situation: - So ein Scheißwetter, dabei ist es bereits Mai! - Das hat dir noch nie gestört, das Dreckwetter; Kann jemand das alles wegschmeißen? Hier liegt überall noch dieses Mistzeug herum! - Es ist mir scheißegal, tu, was du willst! - Wieso soll ich diese Sauarbeit machen? („Bella Martha”).

Blasphemous expressions as a part of confrontational communication is a controversial question, as soon as their current usage presupposes a great 
range of situations - from positive ones to familiar and drastically conflict ones. Situational conflict direction in the family discourse may be implemented by blasphemous expressions (Gott verdamm mich! Himmel noch (ein)mal! Himmel, Kreuz, Donnerwetter! Himmel und Holle! Teufel noch (ein)mal! Pfui Teufel! Im Teufelsnamen! Hol's der Teufel! Sakrament!): - Kannst du mir denn mal genau zuhören, wenn ich etwas erkläre, Teufel noch mal! Himmelherrgott, mach endlich das Radio leiser! - Jesus, Maria, lass mich doch in Ruh!

In conclusion, the German confrontational matrimonial discourse is a background for the usage of a wide socially and situationally determined range of pejorative expressions, which usually mark the highest level of emotionality of a conflict between spouses / partners.

\section{CONCLUSIONS}

'Family' semiotic space includes verbal (lexical nominators of people, objects and events, precedential expressions, texts, genres) and non-verbal (kisses, embraces, engagement rings, family emblems, heritable artifacts) signs with specific meaning, which not only implement an idea about typical patterns of behaviour in family sphere, but also become the core symbols in the German people consciousness. Symbolism of a 'family' sign is stipulated by the common apperception basis and precedence - an experience within collective cognitive space that determines self-identification of a person as a family representative. In a family member's consciousness 'family' symbol activates specific scheme of situation with fixed conditions of expression, existence of which in a recipient's consciousness gives him an ability to comprehend it.

The major sphere of the German family discourse semiotics consists of specific lexical items - inner family denominations, jargonisms, colloquialisms, dialectisms, sexualisms. Family lexicon unites peculiar appellations (names, feel-onyms, zoonims with various word-forming derivatives); diminutive, emotional-evaluative, synonymic, antonymic, individually creative forms of proper names, which through indexation gain positive or negative connotations, symbolizing a type of the family discourse; inner family nicknames semantically different denominations, which without name of denotat get correspondence only within a family group, as soon as they implicate a meaning that juxtaposes denomination with a sphere of origin (appearance, features, habits); inner family new formations, which are created as the result of an innovation in speech or the homonyms creation by a division of lexical meanings of a word and weakening of connection between them.

Substandard phenomena (slang and dialect) are significant elements of

the lexical basis of the German family discourse. The German family slang contains specific words and expressions, which characterize the nature and peculiarity of the family coexistence, demonstrate special features of a family 
communication, function inclusively showing affiliation to a group. Language play as a feature of slang is relevant, first of all, for the matrimonial discourse as a type with social status equality of participants, while cryptolalic - for the parental discourse of different social level.

Marking of strategy in the German family discourse is accomplished by the usage of certain patterns and individual means, which for the family members become associated with cooperative or confrontational behaviour. Among the activators of the global strategies in the German family discourse are peculiar items of language inherently cooperative or confrontational subsystems, which in speakers' consciousness 'switch on' the relevant meanings: intimate vocabulary and language play in cooperative family discourse, and invectives - in confrontational one.

\section{SUMMARY}

The article represents the results of a research of lexical-semantic space of the modern German family discourse - familect, the core feature of which is the family lexicon. As semiotic background, its items include verbal and nonverbal signs, which implement the notions of the typical patterns of behaviour in the family sphere and become the core symbols in the German people consciousness. Symbolism of a 'family' sign is stipulated by the common apperception basis and precedence - an experience within collective cognitive space. The major sphere of the German family discourse semiotics consists of specific lexical items - inner family denominations, jargonisms, colloquialisms, dialectisms, sexualisms. Substandard phenomena (slang and dialect) are significant elements of the lexical basis of the German family discourse.

\section{REFERENCES}

1. Байкулова А. Н. Речевое общение в семье: дисс. ... канд. филол. наук: 10.02.01. Саратовский госуниверситет. Саратов, 2006. 290 с.

2. Занадворова А. В. Прозвище и обращение в семейном речевом общении. Русский язык сегодня. М.: Азбуковник, 2001. С. 260-267.

3. Борисова И. Н. Русский разговорный диалог: структура и динамика. М.: КомКнига, 2005. 320 с.

4. Галапчук О.М. Вікова диференціація стратегій і тактик дискурсу в сучасній англійській мові: автореф. дис. ... канд. філол. наук: 10.02.04. Харківський нац. ун-т. Харків, 2000. 18 с.

5. Піщікова К. В. Стратегії домінування в аргументативному дискурсі: гендерний аналіз (на матеріалі англійської мови): автореф. дис... канд. філол. наук: 10.02.04. Харків, 2003. 23 с.

6. Бігарі А. А. Дискурс сучасної англомовної сім'ї: автореф. дис... канд. філол. наук: 10.02.04. К., 2006. 21 с. 
7. Гридасова О. І. Особливості актуалізації стереотипних ролей в англомовному сімейному конфліктному дискурсі: автореф. дис... канд. філол. наук: 10.02.04. Харків, 2010. 24 с.

8. Смирнова А. Г. Функционально-стилистическое своеобразие семейной речи (на материале немецкого языка): дисс. ... канд. филол. наук: 10.02.04. М., 2008. 178 c.

9. Mackeldey R. Alltagssprachliche Dialoge: Kommunikative Funktionen und syntaktische Strukturen. Leipzig: Enzyklopädie, 1987. 160 S.

10. Spiegel C. Streit: eine linguistische Untersuchung verbaler Interaktionen in alltäglichen Zusammenhängen. Tübingen: Narr, 1995. 326 S.

11. Романова Е. В. Этический аспект немецкого обиходного языка: дисс. ... канд. филол. наук: 10.02.04. М.: МГПИИЯ, 2007. 315 с.

12. Haferland H., Paul I. Eine Theorie der Höflichkeit. Osnabrücker Beiträge zur Sprachtheorie. 1996. 52. S. 7-69.

13. Leisi E. Paar und Sprache. 3. Auflage. Quelle\&Meyer HedelbergWiesbaden, 1990. 167 S. 1992. $240 \mathrm{~S}$.

14. Loewit K. Die Sprache der Sexualität. Frankfurt am Main,

15. Нефёдова Л. А. Явление девиации в лексике современного немецкого языка: монография. М.: Прометей, 2002. 260 с.

16. Fiehler R. Kommunikation zwischen den Generationen: Wunschvorstellung oder Wirklichkeit? L.O.G.O.S. Interdisziplinär. 2007. № 15, 3. S. 200-207.

17. Kratzmeier H. Du nervst mich, aber ich mag dich: Fragwürdige Sprüche von Eltern und Großeltern. Hildesheim: Bernward, 1988. 88 S.

18. Osovska I. The analysis of semiotics of the family language as a verbalized area of family discourse. Technology transfer: innovative solutions in Social Sciences and Humanities. Tallinn, 2018. Pp. 3-6.

19. Осовська I.M. Сучасний німецький сімейний дискурс: когнітивно-семантичний і комунікативно-прагматичний виміри: дис. ... д-ра філол. наук: 10.02.04. Чернівці, 2014. 474 с.

20.Занадворова А. В. Прозвище и обращение в семейном речевом общении. Русский язык сегодня. М.: Азбуковник, 2001. С. 260-267.

21. Семенюк А. А. Гендерні та вікові особливості кооперативної мовленнєвої поведінки в сімейному дискурсі (на матеріалі сучасної англійської мови): автореф. дис. ... канд. філол. наук: 10.02.04. Донецьк, 2007. 27 c.

22. Лотман Ю. М. Семиосфера. СПб.: Искусство, 2004. 704 с.

23. Шаумян С. О понятии языкового знака. Язык и культура: факты и ценности: К 70-летию Юрия Сергеевича Степанова: Отв. ред. Е. С. Кубрякова, Т. Е. Янко. М.: Языки славянской культуры, 2001. С. 149-165. 
24. Комарова 3. И. Методология, метод, методика и технология научных иследований в лингвистике. 2-е изд., испр. и доп. М.: Флинта: Наука, 2013. 820 c.

25. Osovska I. The analysis of semiotics of the family language as a verbalized area of family discourse. Technology transfer: innovative solutions in Social Sciences and Humanities. Tallinn, 2018. Pp. 3-6.

26. Осовська I.M. Сучасний німецький сімейний дискурс: когнітивно-семантичний і комунікативно-прагматичний виміри: дис. ... д-ра філол. наук: 10.02.04. Чернівці, 2014. 474 с.

27. Пирс Ч. С. Избранные философские произведения. М.: Логос, $2000.416 \mathrm{c}$.

28. Osovska I. The analysis of semiotics of the family language as a verbalized area of family discourse. Technology transfer: innovative solutions in Social Sciences and Humanities. Tallinn, 2018. Pp. 3-6.

29. Красавский Н. А. Эмоциональные концепты в немецкой и русской лингвокультурах: монография. М.: Гнозис, 2008. 374 с.

30. Osovska I. The analysis of semiotics of the family language as a verbalized area of family discourse. Technology transfer: innovative solutions in Social Sciences and Humanities. Tallinn, 2018. Pp. 3-6.

31. Осовська I.M. Сучасний німецький сімейний дискурс: когнітивно-семантичний і комунікативно-прагматичний виміри: дис. ... д-ра філол. наук: 10.02.04. Чернівці, 2014. 474 с.

32. Heinemann M. Kleines Wörterbuch der Jugendsprache. Leipzig: Bibliographisches Institut, 1989. 122 S.

33. Löffler H. Germanistische Soziolinguistik. Berlin: Erich Schmidt Verlag, 1994. $240 \mathrm{~S}$.

34. Меркурьева В. Б. Литературный язык и диалект в естественной и художественной коммуникации. Теория и история германских $и$ романских языков в современной высшей школе России. Калуга: Изд-во Калужского госпедуниверситета, 2002. С. 21-27.

35. URL: http://staff-www.uni-marburg.de/ naeser/dial-bsp.htm.

36. Ренц Т. Г. Романтическое общение в коммуникативно-семиотическом аспекте: автореф. дисс. ... д-ра филол. наук: 10.02.19. Волгоград, $2011.42 \mathrm{c}$.

37. Poth C. Taktik des Ehekrieges. Fischer Taschenbuch Verlag, 1996. Bd. 2484.

38. Leisi E. Paar und Sprache. 3. Auflage. Quelle\&Meyer HedelbergWiesbaden, 1990. $167 \mathrm{~S}$.

39. Deppert A. Die Metapher als semantisches Wortbildungsmuster bei englischen und deutschen Bezeichnungen für Geschlechtsverkehr. 
Sprache - Erotik - Sexualität. Hobert R. (Hrsg). Berlin: Erich Schmidt Verlag, 2001. S. 128-157.

40. Санников В. 3. Русский язык в зеркале языковой игры. М.: Языки русской культуры, 1999. 541 с.

41. Осовська I.M. Сучасний німецький сімейний дискурс: когнітивно-семантичний і комунікативно-прагматичний виміри: дис. ... д-ра філол. наук: 10.02.04. Чернівці, 2014. 474 с.

42. Müller H. Heute wär ich mir lieber nicht begegnet. Frankfurt am Main: Fischer Taschenbuch Verlag, 2010. 240 S.

43. Жельвис В. И. Поле брани. Сквернословие как социальная проблема в языках и культурах мира. М.: Ладомир, 1997. 230 с.

44. Форманова С. В. Інвективи в українській мові: автореф. дис. ... д-ра філол. наук: 10.02.01. Одеса: ОНУ імені І. І. Мечникова, 2013. 39 с.

\section{Information about the author:}

Osovska I. M.,

Doctor of Philology, Professor at the Department of Germanic, General and Comparative Linguistics, Yuriy Fedkovych Chernivtsi National University 2, M. Kozyubynskogo str., Chernivtsi, 58002, Ukraine 